\title{
Understanding Employee Brand Trust and Internal Brand Communications \& Training (BCT) Effects on Employee Brand Performance: A study of the banking industry
}

Shoaib Muhammad ${ }^{1 *}$, Salniza Salleh ${ }^{2}$, Maha Mohammed Yusr ${ }^{3}$

School of Business Management, (SBM), University Utara Malaysia, Sintok, Kedah, Malaysia ${ }^{1,2,3}$ shoaib2k@yahoo.com ${ }^{1 *}$ sal1029@uum.edu.my ${ }^{2}$

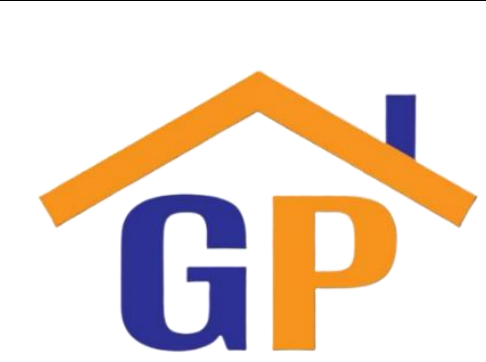

Article History

Received on 16 July 2020

1st Revision on 20 July 2020

$2^{\text {nd }}$ Revision on 29 July 2020

Accepted on 30 July 2020

\begin{abstract}
Purpose: The present study aims to examine the impact of key internal branding practices on affective brand commitment (AC) and employee brand performance (EBP) in the financial services industry. Also assessed was the mediating role of $\mathrm{AC}$ in the relationship of brand trust, brand communication and training (BCT), and EBP.
\end{abstract}

Research Methodology: A quantitative survey tool was employed to gather data from 426 respondents from public-sector banks in Pakistan. The sampling methods used were a combination of proportionate random and convenience sampling techniques. The partial least squares-structural equation modelling (PLS-SEM) was used to analyze and interpret the data.

Results: Findings indicate that the relationship of brand trust, BCT and EBP was mediated by AC. Brand trust and BCT results in higher levels of bank staff's AC; this employee affective attachment to the bank brand drive them to engage in brand supporting behaviors, which in turn, foster employee brand performance.

Limitations: This study is limited by scope as only public sector banks were studied, which may not be sufficient to make an inference.

Contribution: BCT and trust are critical drivers fostering EBP and brand success; however, AC in the relation ensures EBP remains either the same or higher in the long run. Hence, banking, and other service firms should focus on improving EBP to develop a strong and successful corporate brand.

Keywords: Brand commitment, Internal brand communications, Brand training, Internal branding, Perceived organizational support (POS),Brand performance, Public Banks, IPMA analysis.

How to cite: Muhammad, S., Salleh, S. M., Yusr, M. M. (2020). Understanding Employee Brand Trust and Internal Brand Communications \& Training (BCT) Effects on Employee Brand Performance: A study of the banking industry. International Journal of Financial, Accounting, and Management, 95-120.

\section{Introduction}

Employee behavior is key to customer satisfaction, loyalty, and brand success; however, only a few studies consider views of internal stakeholders view (e.g., employees) in their studies (e.g., Buil, Catalán, \& Martínez 2016; Burmann et al., 2009). Internal marketing or internal brand management (IBM) practices are not well received or understood by many service firms and other businesses (Wang, Yang \& Yang, 2019). A brand is perceived as a commitment or promises to service companies (Ambler \& Styles, 1996; Berry, 2000). The behavioral intention and role of the company's employees are vital 
as their brand-aligned performance during successful service encounters with external customers brings actual service promise to practice (Punjaisri \& Wilson, 2011; Wallace, de Chernatony \& Buil, 2013). From an IBM perspective, the study has significance for the financial services industry, such as the banking sector, especially affected by the worst global financial crisis (GFC) and economic shocks. Indeed, the GFC had a crippling effect on customer confidence, trust, and eventually impacted banks' overall resilience (Colton \& Oliveira, 2009). Banks and other financial companies are seeking to develop corporate brands to regain customer trust, improve their relationships with the corporate brand, and create happy and more loyal bank customers (Wallace, de Chernatony, \& Buil, 2011). Company employees are a credible source of corporate brand differentiation and a sustainable competitive advantage. Service firms can improve employee delivery of brand-consistent promises (expectations) through their cognitive and affective commitment to the brand they work for. Developing and fostering an affective commitment (AC) of employees to the service brand can drive company brand performance and help to rebuild customer trust in financial services brands. Employee brand performance (EBP) constitutes a significant part of customers' overall perception of service quality and evaluations/or expectations of the corporate brand within the service industry setting. In this sense, EBP has been proposed by services marketing and corporate branding literature as the desired outcome of a successful IBM strategy (Mampaey et al., 2020).

Service firms intent to establish an excellent internal (branding) work atmosphere in which employee affective commitment and superior EBP are supported and encouraged (de Chernatony \& Cottam, 2006; Muhammad et al., 2019; Vatankhah \& Darvishi, 2018). Internal branding (IB) a sub-category of internal marketing orientation (IMO) is broadly implemented in all types of industry, including service firms, to ensure that EBP is in line with previous consumer perceptions of the brand and perceived service quality expectations (Xiong, 2014). More significantly, banks cannot afford negative behaviour from bank employees while delivering on the expected level of service (Pramanik \& Chatterjee, 2015). Increasing attention has been paid to exploring antecedents of EBP, which is one of the critical antecedents of employee brand-aligned attitude and behaviour, authentic service delivery commitment, and emotionally supporting the internal brand-building efforts of service companies (Buil et al., 2019; Burmann \& Zeplin, 2005; Kim \& Brymer, 2011; Punjaisri et al., 2009; Xiong et al., 2013).

King et al. (2012) note that employee behaviour is the only true predictor of organisational effectiveness when adopting a company-wide internal marketing and brand management strategy. In other words, congruent behaviour and attitude among employees is a prerequisite for internal and external branding efforts to succeed (Iyer et al., 2018). Although a few studies have so far tried to address what is required for an appropriate IBM and business strategy to realize favorable EBP (Punjaisri \& Wilson, 2007, 2011), not much is known in the current literature what is appropriate employee behaviour that can affect and capture desired employee brand performance (Iyer, Davari, \& Paswan, 2018; Shaari, 2013). The current study addresses the call for a better understanding of the valuable role of the insiders in improving the brand performance of the company brand through its higher-role expectations and brandaligned service delivery performance (Iyer et al., 2019).

Trust is linked not only to individuals but also to firms, products, and brands (Ganesan \& Hess, 1997). This paper considers construct of trust as an antecedent of employee affective commitment as relationship marketing paradigm (Gronroos, 1994) argue that individual members are unlikely to be cognitively and affectively committed to the organization (or brand) unless trust in the relationship has already accomplished (Garbarino \& Johnson, 1999). In general, from a relationship marketing perspective, commitment is a part of the ongoing process of assuring and preserving a given relationship (e.g., employee-brand relationship) and trust is the primary reason for its existence (Chaudhuri \& Holbrook, 2002). Reichhed and Schefter (2000) stress the significance of trust in relation to customer loyalty and retention by claiming that "to gain the loyalty of customers, you must first gain trust". Similarly, in the IBM setting, to gain an employee commitment to the company brand, and, in effect, inform their brand performance, service firms must first gain their trust. Commitment in a given relationship derives its power from the trust. It can be argued that trust is a primary antecedent that increases employee commitment and loyalty with the brand (Erkmen et al., 2017). According to several academic researchers, despite the relevance and significance of trust and commitment constructs, 
insufficient attention has been paid to explore empirically those critical factors involving trust and commitment as well as employee brand performance in marketing-driven exchange relationships (Erkmen \& Hancer, 2015; Gounaris, 2005). The first objective of this study is, therefore, to address this knowledge gap by highlighting the specific role of employee trust for its direct effect on bank employee affective commitment, working in public sector banks in Pakistan.

Customers expect and value consistency in performance from their service providers by basing their service brand impressions/or expectations on previous successful brand experiences. Even though consumer experience a company's service or marketing offer directly, they typically need to access service quality at each point of service interaction due to inconsistency in employee actual service behaviors (actions) or variability in service delivery performance (Zeithaml et al., 1985). For this reason, it is argued that IBM has particular relevance and significance to service businesses, where a key challenge is to overcome or reduce service performance variability arises at the point of actual service delivery at each individual interaction with customers (Berry, 2000; Norman, 2000). Garas et al. (2018) contend that due to variability or inconsistency in employee behavior and service delivery performance, two potential gaps might arise. The first one is related to inconsistency in internal and external brand communication dissemination (also known as corporate communication gap), which captures and reflects the difference between externally communicated (advertised) corporate brand promise and actual brand promise delivery. This corporate brand communication gap can be effectively managed by formal organizational support systems (or vertical formal support systems) such as appropriate internal communication practices and employee brand-centred training programs that enable employees to align their attitude and behavior and deliver consistently on promised service quality in order to create a seamless authentic brand experience for external customers. The second gap is related to service performance, which reflects the difference between predetermined service brand standards and actual service delivery (Garas et al., 2018). The possible reasons for the service performance gap include service personnel who are not either adequately trained, noncompliant or incapable of meeting the service brand standards; evidently in the absence of an appropriate and meaningful internal brand communication dissemination (e.g., lack of competence in product knowledge, skills, expertise, and motivation) leads to increase in role ambiguity and role confusion, further decrease service employees' brand confidence in delivering the desired service experience (King \& Grace, 2010; Piehler, 2018), in turn, lead to negatively impacting on employees' affective commitment (AC) to deliver a good service quality and brand promise to fulfil customers need as enacted by the brand standards (Meyer et al., 2002; Xiong \& King, 2019). Such service brand variations or inconsistencies must be overcome in order to realize a sustainable competitive advantage. Besides that, a higher level of employee AC is regarded as one of the key outcomes of good internal communication practices (Burmann \& Zeplin, 2005; King, 2010; Miles, Mangold, Asree, \& Revell, 2011; Xiong, King, \& Piehler, 2013). Employee AC enables them to behave like brand champions, where they are emotionally committed to 'living the brand' (Ind, 2004), as they understand correctly what is expected of them and deliver on their higher role expectations according to enacted service brand standards. However, instilling affective commitment among service personnel is still a challenging task for many service businesses and other companies in different industries/sectors, and hence, difficult to achieve successfully (Burmann, Zeplin, \& Riley, 2009; Muhammad et al., 2019; Xiong \& King, 2015).

To date, only a few works have incorporated employee brand trust as an additional dimension of internal branding, to inform EBP (e.g., Erkmen \& Hancer, 2015; Erkmen, Hancer \& Leong, 2017 ). This study integrates the organisational support theory (Eisenberger et al., 1990) and commitment-trust relationship marketing theory (Hunt \& Morgan, 1994) to address how the adoption of IBM can enhance employee affective brand commitment and EBP within the Pakistan banking service setting by enhancing their brand trust, brand communications and brand training levels. A set of hypotheses is developed in the current research paper to examine if employee internal branding practices result in EBP (e.g., desirable service behaviour), mediated by their affective brand commitment (e.g., attitude). 


\section{Theory and hypothesis development}

\subsection{Perceived organisational support theory (POS) and employee brand performance}

Perceived organizational support (POS) align employees' brand performance with the company purpose (Xiong et al., 2019). Furthermore, as guided by perceived organisational support (POS) theory, which is one of the important components of the social exchange framework, captures to what extent employees believe that the service provider understands, appreciates and values their positive brand/or work-related efforts, genuinely pay attention to their well-being and keep its promises (Eisenberger et al., 1990; Rhoades \& Eisenberger, 2002). Particularly in the IBM context, POS reflects workforce quality assessment of the service provider's earlier contributions to their exchange relationship (Löhndorf \& Diamantopoulos, 2014). Chiang et al. (2011) underscore that insiders' performance greatly hinges on the quality of perceived organisational support (POS). King and So (2015) describe POS (or employee brand-oriented support) as service employees' general perceptions concerning the extent to which service firm assists and supports them in developing appropriate attitude, brand-specific knowledge (understanding values, promises and customer's needs), skills, which is imperative for service staff to elicit more BCB. Besides, past authors (e.g., Buil et al., 2016; Garg \& Dhar, 2014; Dhiman \& Arora 2019; King \& So, 2015; Löhndorf \& Diamantopoulos, 2014; Terglav et al., 2016; Xie et al., 2014; Xiong \& King, 2018, 2019) have contended the more service employees perceived favorable brand-oriented support from top executives and managers, they will exert positive BCB or EBP as postulated by the social exchange theory.

As guided by formal POS framework, when service workers strongly identified and believed that they are well- supported and guided by their service firms (extrinsic and intrinsic support ), further, that employer appreciates and highly valued their contributions, hence, service personnel will perceive high levels of positive POS and, thus, are more likely to be motivated and engaged in brand supporting behaviors and return favor to service firm with higher levels of affective commitment and increase their in-role and extra-role citizenship behaviours that are favorable to the service firm both on and off the job (Hayton et al., 2012; Löhndorf \& Diamantopoulos, 2014; Rhoades \& Eisenberger, 2002).

Additionally, POS should provide valuable feedback to service personnel on their job or brand-related performance (King \& Grace, 2009, 2010; Miles \& Mangold, 2004; Xiong et al., 2013). Specifically, in the IBM or service organizational context, employees must perceive that brand is meaningful for their work and it is crucial for organizations' (or brand) success before they can develop coveted attitudes and behaviors. That is, the more employees believe bank brand positively, the more they exert positive attitude and behavior towards the bank brand they work for. In sum, such internal support systems are a more robust driver and a key enabler of employee brand-supportive performance behavior.

Recent IBM studies indicated that dimensions of formal organizational support mechanism such as brand-centred training and internal communications practice contribute significantly towards employee BCB in order to support and act in favor of the service brand positively (Buil et al., 2016; King \& So, 2015; Terglav et al., 2016; Xiong \& King, 2018). Xiong and King (2018) contend POS support mechanism is key for the services industry as it could advance employee service performance where workforce face extremely high work overload, role ambiguity and conflict, and more importantly, their brand performance delivery represents a most significant part of customers evaluations (selfperceptions) of perceived service quality of the brand to be used within the specific service situations. Contrary to positive POS effects, when insiders' brand perceptions, attitude and behaviours are not congruent with organizations' brand-related expectations like service quality, congruent service delivery, brand credibility and customer satisfaction, their behaviour or actions may cause unintended damage to service firm brand credibility and brand image (Xiong \& King, 2019). In the broader organizational context, POS framework acts like an internal regulator that turns employees perception and attitude in favor of the service brand (Dhiman \& Arora, 2019).

\subsection{Trust-commitment theory and employee brand performance}

Current IBM literature accepts and underscores the relevance and critical role of employee affective brand commitment (AC) in company brand success, particularly in the service industry (Du Preez \& 
Bendixen, 2015; Kimpakorn \& Tocquer, 2010; Yang et al., 2015). While delivering an appropriate externally communicated brand promise/or experience, and customer emotional attachment with the company brand can be effectively achieved by staff members AC to the company brand (Koo \& Curtis, 2019). Just as the behavioral intention is regarded as the result of an attitude, (Fishbein \& Ajzen, 1975), the commitment-trust theory (CTT) of relationship marketing (Hunt \& Morgan, 1994) postulates that commitment in a relationship is the result of affective trust. Furthermore, the high interdependency between trust and commitment and according to the theory of relationship marketing (Gronroos, 1994), trust and commitment constructs are considered indispensable and interdependent (Wang, 2009). Besides that, according to some researchers, trust precedes commitment in a relationship and indicates a causal relation. Like in all other meaningful relations, the construct of trust is considered an important and prerequisite element, which not only positively affects commitment but also enhances the value/or quality of relationships particularly within the realm of service branding (Bowden, 2009).

Past studies pertaining to IBM has empirically demonstrated and identified employee AC as one of the most desired outcomes of successful internal branding efforts (e.g., Burmann \& Zeplin, 2005; King \& Grace, 2012) that forcefully impact on employee brand-supportive behaviours (in and extra-brand supporting behaviors). However, previous works have ignored the central conduit of employee brand trust to explain better both AC as an attitude and employee citizenship behavior or EBP as a behavioral intention (Erkmen, Hancer \& Leong, 2017). Despite its importance and relevance in the services marketing literature, far too little attention has been paid to comprehend how staff members form their relationship with the service provider, hence brand, and ultimately become highly motivated and affectively committed to supporting the service brand both through their behavior (brand actions) and brand-aligned performance (Aurand et al., 2005; Erkmen \& Hancer, 2015; Yang et al., 2015). Morgan \& Hunt, (1994) define trust construct as "existing when one party has confidence in the exchange partner's reliability and integrity." In other words, once employees have bitter understanding, confidence in a brand's reliability (safety), honesty, and integrity (e.g., brand's ability to perform its stated function and deliver on the brand promise) they will develop an AC to act in a brand-consistent way as the result of a higher degree of employee affective brand trust. Internal branding literature also supports that service staff display a better understanding and a sense of identification or sense of belonging, and $\mathrm{AC}$ to the corporate brand when they have a high level of trust, mutual respect and loyalty for the company (brand) they work for (Chen \& Klimoski, 2003; Lewicki \& Bunker, 1996). Following this line of thought to the employee-brand relationship, enhancing company employee trust in a service brand positively affects on their AC and perceived brand trustworthiness, in turn, trigger employee behavior to engage in favorable brand-citizenship (in and extra-role) behaviours to advance the brand positively (Chaudhri \& Holbrook, 2002).

Further, it is assumed that when both affective trust and commitment are maintained, positive outcomes can be anticipated. Besides the relationship-building role, the trust construct has also been suggested as a significant contributing factor towards BCB or EBP (Delgado-Ballester \& Munuera-Alemán, 2001; Gilani, 2019). For instance, Erkmen and Hancer (2015) report that the positive effects of affective commitment on EBP could be better explained via brand trust, which is consistent with the CCT of relationship marketing (Morgan \& Hunt, 1994), that indicates a causal relationship between trust and commitment. In other words, trust precedes commitment in a relationship. That is as employees' brand trust increases, employees' tendency to adopting brand supporting behaviour also increases (Erkmen \& Hancer, 2015; Erkmen, Hancer, \& Leong, 2017). Thus, it can be theorized that brand commitment and brand trust are two critical antecedents of EBP (Gilani, 2019).

\subsection{Employee brand trust}

Due to its growing importance in a given relationship, particularly in organisational or internal branding settings, trust construct has drawn increasing attention from both business practitioners and academic researchers in recent years (Alhaddad, 2015). According to McAllister (1995), trust is a special kind of attitude that evokes a specific behaviour such as commitment. Therefore, organizations need to gain and win employee trust (Khalil \& Siddiqui, 2019; Wang \& Hsieh, 2013). In general, it is assumed that employees' AC and employees' brand performance depend on how much employees trust and show confidence in their company's products and services under its brand. In the fast-changing and 
increasingly competitive corporate sector landscape particularly in the service industry, where employee behaviours are highly valued as it adds greater efficiency to company sustainable performance and business success; however, it is witnessed that there has been an overall decline of trust in the company (brand) amongst organizational members (Singh \& Srivastava, 2016).

According to the commitment-trust theory (CCT) of relationship marketing (Morgan \& Hunt, 1994), trust has been suggested to be a most influential and identified determinant that explain and inform employee AC to the brand and individual members' desire to stay in a long-term relationship with a company (loyalty behavior), hence brand (Erkmen \& Hancer, 2015). Moorman et al. (1992) describe trust as "a willingness to rely on an exchange partner in whom one has confidence." Whereas Chaudhuri and Holbrook (2001) define brand trust as "the willingness of the average consumer to rely on the ability of the brand to perform its stated function." However, specifically in the IBM setting, Kimpakorn and Tocquer (2010) state that trust is measured by the ability of the brand to deliver on its stated promise or purpose. Hence, in the present study context, employee brand trust is described as the willingness and commitment of an employee to rely on the company capabilities, internal human and other resources to perform its brand delivery obligation successfully (Chaudhuri \& Holbrook 2001) and advancing genuine brand experience to customers in order to benefit the service brand. Therefore, it is justifiable to inform employee AC through employee brand trust because the objective of IBM is to have a brandcommitted and brand-aligned workforce strongly demonstrate trust and confidence in the company's ability to consistently deliver on its communicated brand promise. More specifically, they will develop and maintain a higher level of AC to deliver the desired brand promise and are more likely to involve in a favorable brand supporting and customer-oriented behaviors (Erkmen, Hancer \& Leong, 2017).

A general agreement exists among the scholars and management practitioners about the primary relation between trust-commitment in various industries and disciplines (Yao, Qiu \& Wei, 2019). Many studies in other sectors, for instance, airline, automobile and hotel industry etc. also suggested that trust has a positive effect on commitment (Chiang \& Wang, 2012; Cho \& Park, 2011; Erkmen \& Hancer, 2015; Kimpakorn \& Tocquer, 2009; Lee, Kim \& Chan-Olmsted 2011; Morgan \& Hunt, 1994) and OCB (Dirks \& Ferrin, 2002; Yakovleva, Reilly \& Werko, 2010). Further, this study theorized that successful relational exchanges among employees-management at the organisational level are primarily driven by trust and commitment. Additionally, rather than focusing on individuals' trust, this study examines employees' trust in an organisation' brand, captured as employees confidence in the quality and reliability of the services delivered. Both theoretical and empirical viewpoints propose that trust may result in employee brand supporting behaviours that leads to higher employee AC and brand performance. Thus, the study makes the following hypothesis:

H1: Employee brand trust will have a significant and positive impact on employee affective brand commitment.

\subsection{Brand communication and training (BCT)}

The current brand management literature and studies have identified internal brand communications' (IBC) pivotal role in fostering EBP (King \& Grace, 2010, 2012; Morhart et al., 2009: Punjaisri et al., 2009; Punjaisri \& Wilson, 2011). Piehler et al., (2015) define it as "brand communication is one of the most powerful managerial tools to inform employees about the brand, to build affective attachment, and to influence employee behaviour." The branding literature strongly emphasizes the importance of consistent brand communication dissemination for internal branding success (Du Preez \& Bendixen, 2015; Hofer \& Grohs, 2018). To better comprehend affects and consequences of internal communications on employee behavior and subsequent performance, several attempts have been made to operationalize or conceptualize this construct specifically in the IBM setting, despite the differences exist how to define or explain IBC (e.g., Boukis et al., 2017; King, 2010, King et al., 2013; Liu et al., 2017; Yu et al., 2018), all authors claim that effective IBC activities directed at internal audience such as employees at all levels, could generate a number of a useful employee or IBM outcomes like affective organizational commitment (Burmann et al., 2009; Garas et al., 2018; King, 2010; Punjaisri\& Wilson, 2011), and employee BCB among others (Burmann et al.,2009; Baker et al., 2013; Porricelli et al., 2014). 
To achieve employee brand-consistent and service performance delivery objectives, companies usually employ all types of internal communication channels/or tools to transmit its core brand identity, values and messages; however, the two primary message delivery systems of IBC, as perceived by the employees are group meetings and brand-centred training and identified them as effective tools of internal communication practices and internal marketing campaigns (Leijerholt, Chapleo \& O' Sullivan, 2019). By integrating IBC into overall corporate IBM and business strategy, service companies attempt to align its strategically important IBC with actual goals, values, products and services so that IBC fully integrated into the thoughts (cognition) and behaviors (actions) of the service personnel in order to 'live the brand' while interacting with external customers and champion the service brand they work for (Leijerholt et al., 2019).

Further, service companies must ensure there are no inadequacies (or inconsistencies) in the perceived service quality, product/or service offerings, brand-aligned customer services, internal and external advertising and marketing campaigns and the actual customer brand experiences. Taking this into consideration, internal communications system and training programs need to secure internal stakeholders cognitive and affective commitment to engage and display pro-actively organizational and brand supporting behaviours. This can be done by educating and training service staff about the corporate brand identity, products, perceived service quality and customer service expectations (Erkmen et al., 2017; King \& Grace, 2009, 2010; Miles \& Mangold, 2004; Piehler et al. 2015; Xiong et al., 2013). That is, the company employees must be equipped with the appropriate product knowledge, right service attitude, competency and tools necessary to deliver on the brand promise. The service company must also ensure real-time and continuous feedback on their performance. Such internal supporting mechanisms enhance employee brand understanding and acceptance of pro-brand behaviors that champion the service brand by internalizing and bringing the abstract brand identity (e.g., brand values or brand meaning) to life for external customers and foster their brand confidence and serviceability in delivering the actual corporate brand values as expected by service firm and other customers explicitly or implicitly.

Designing and developing brand-centred training and orientation programs for frontline employees is a prerequisite for satisfactory service delivery performance; however, it does not mean that there is no need to train and motivate other key insiders such as backstage employees. In this regard, Burmann and König (2012) posit that brand-centred training is the antecedent to the employee affective commitment that drives employees cognitive and affective attachment (e.g., similar to intellectual-buy-in and emotional buy-in as proposed by Thompson et al., 1999) to the corporate brand. Papasolomou and Vrontis (2006) identified brand-oriented training as an enabler of IBC, aimed at cultivating a strong brand understanding and brand awareness among service personnel. Additionally, employee brand training programs (e.g., act as a formal organizational support mechanism) initiated by the service companies to adequately inform and guide service staff brand performance (Punjaisri \& Wilson, 2011; Xiong \& King, 2019). On the contrary, the mere presence of basic service/or brand standards, service procedures, guidelines and coordinated training programs in general service skills may not be sufficient to ensure exceptional service quality delivery in order to realize desired employee brand performance (Xiong \& King, 2019). In this regard, corporate business leaders and managers should assist and enable employees to develop a right service attitude, competency and enhance their perceived brand understanding that customer satisfaction and service brand success is everyone's responsibility, through the adoption of suitable IBC strategy (Xiong \& King, 2019).

Studies on IBM have found statistically supported evidence that internal communications and training activities positively affects employees affective organizational commitment and employee brand performance (Burmann et al., 2009; Camilleri, 2008; Du Preez \& Bendixen, 2015; Porricelli et al., 2014; Punjaisri \& Wilson, 2011; Yang et al., 2015; Yurova et al., 2014). However, surprisingly, the study of Erkmen (2018) found no effect of internal communications on employees affective commitment. Notably, in the extant internal marketing literature, there is no consensus on the appropriate internal branding practices. Hence, to achieve the present study's research aims, this study adopts a functional approach to IBM as adopted by Punjaisri and Wilson in their works $(2007,2011)$. Who studied the impacts of IBM tools (e.g., internal communication practices and brand-centred training programs) on 
EBP. They suggested that these practices are the fundamental IBM tools or internal mechanisms to create and facilitate behavioral changes to enhance EBP. Besides that, these formal (vertical) organizational support systems help employees to develop and maintain service brand standards (Punjaisri et al., 2008). Hence, the study proposes the following hypothesis:

H2: Internal brand communications and training (BCT) will have a significant and positive impact on employee affective brand commitment.

\subsection{Effects of affective brand commitment on employee brand performance}

Commitment construct is a central concept both in marketing and brand management fields because of its significant influence in shaping and transforming employee perceptions, attitudes, and behaviors in favor of employer brand (Buil, Catalán, \& Martínez, 2016). Burmann and Zeplin (2005) describe brand commitment (BC) construct in the broader organizational perspective as the extent of employees cognitive and affective engagement or feelings towards the company's brand they work for. They further add that in order to achieve organisational and brand success, employees need to exhibit higher level $\mathrm{BC}$ in order to strengthen corporate brand identity and image. The operationalization or conceptualization of this construct is not consistent in the IBM or internal marketing literature. However, most researches explain BC as an affective commitment (King \& Grace, 2012; Piehler et al., 2015, 2016) or cognitive commitment (Punjaisri \& Wilson, 2011). In other words, internal service employees with AC strengthen and reinforce corporate brand through their consistent attitude and behaviors. Service enterprises usually expect more from their internal audience in terms of in-role and extra-role brand building/or citizenship behaviors then basic organizational membership (e.g., similar to normative and continuance forms of commitment) or intention to stay with the service firm (Piehler et al., 2016). Construct commitment in the organizational and more specifically in the internal branding setting entails to identify those critical elements that encourage and contributes to staff members probrand attitude and behaviors (King \& Grace, 2009; Piehler et al., 2016). This study argues that BC of company employees is one-dimensional as AC that portrays and captures employee affective attachment or feelings of belonging to the bank brand. In a dynamic and increasingly competitive service environment, organizations expect consistent and sustained from insiders in order to deliver the actual brand experience in the most genuine manner. Besides that, $\mathrm{AC}$ is an important determinant and antecedent of employee favorable BCB or EBP (King \& Grace, 2012: Punjaisri et al., 2009; Piehler et al., 2016). Earlier Burmann and Zeplin (2005) in their research indicate this positive impact on the premises of $\mathrm{OB}$ literature that also suggests a positive and robust impact of organizational (brand) commitment on employee OCB (Meyer \& Allen, 1997; Podsakoff et al., 2000). Likewise, in the internal marketing/IB setting, few studies also suggest a positive effect of AC on employee BCB (King \& Grace, 2010, 2012; Xiong et al., 2013). Organizational commitment theory (Cook \& Wall, 1980) indicate that service employees are more likely to develop AC towards one's organization, if they perceive that focal brand is important and meaningful for them and enterprise's overall business success, they will accept and internalize the values and goals of the service brand in their heart and mind, and, hence, they are expected to exhibit better work (or brand) performance.

Erkmen and Hancer (2015) assert that from organizational (branding) point of view, AC is significantly important to comprehend how employees embrace BCB and act in accordance with service organization's implicit or explicit expectations. For instance, recent researches in the IBM accepted the $\mathrm{BC}$ of company employees as a significant contributing factor for corporate brand's success, especially in the services industry (de Chernatony et al., 2003; Du Preez \& Bendixen, 2015; Koo \& Curtis, 2019). Yang et al. (2015) examine the effects of key IB practices on hotel employee's AC and brand-related behaviors working in Taiwan hotel industry, conclude that hotel managers should consider emphasis and reinforce brand values and messages through coordinated brand-centred training activities, in order to enhance organizational members AC, that will guide to better EBP. Likewise, Piehler et al. (2016) study also identified that AC is a significantly important determinant of employees' favorable BCB. That is because, when employees understand, accept, and internalize the company's brand values and goals, they will be more engaged and committed towards the service employer brand, in turn, encourage and increase their brand citizenship behaviors or brand performance (Koo \& Curtis, 2019). Hence, according to IBM and attitudinal literature ((Rosenberg \& Hovland, 1960), this study expects bank 
employees who strongly exhibit identification with, and cognitively and affectively committed to delivering the bank brand promise in order to champion the bank brand (Piehler et al., 2016; Stuart, 2012), and, in turn, leads to higher levels of sustainable EBP. Based on the aforementioned discussion, the following hypothesis is proposed:

H3: Employee affective brand commitment will have a positive and significant effect on employee brand performance.

\subsection{Mediation effects of brand commitment among employee brand trust and brand communication training and employee brand performance.}

The easiest and effective way to achieve employee brand performance is to keep employee brand trust and internal communication practices and brand-centred training programs at the highest possible level to secure employee affective commitment (AC), which is a strong precursor of EBP and mediator among employee internal branding practices and EBP. Organizational (brand) AC signifies and portrays company employees consistent and positive behavior towards the bank brand they work for and is a central route of employee brand-aligned supportive behaviors (Ravens, 2013). Consistent and sustainable employee AC increases corporate brand values, messages, and enhances company brand success (Piehler et al., 2015). Hence, service staff members in the service industry such as banks should not only understand what the bank brand represents, and stands for (e.g., goals and values), but more specifically, they must affectively committed to the bank brand by consistently delivering the excellent service quality and actual brand experience to influence bank customer's perceptions and enhance customer-brand relationships in order to create satisfied bank customers. In particular, construct brand trust significantly and positively contributes to the employee brand-aligned service delivery performance through its direct influence on employee AC (Delgado-Ballester \& Munuera-Alemán, 2001) and BCB. According to internal marketing literature, internal communication practices and training programs are the most accepted determinants of employee AC (Burmann \& Zeplin 2005; King \& Grace (2010). For instance, few researchers claimed that internal communication dissemination of core brand values and promises is a precursor of employee AC and affects it positively (Bambacus \& Patrickson, 2008; Porricelli, Yurova, Abratt \& Bendixen, 2014). Earlier studies found sufficient support for the construct $\mathrm{AC}$ as a mediation model in the management and IBM setting. For example, Miles and Mangold (2005) strongly underscored the importance of critical mediators among employee internal branding practices and favorable employee/or work-related outcomes. In this regard, only a few studies in IBM framework so far have proposed and used AC as a mediator (Biedenbach \& Manzhynski, 2016; Du Preez \& Bendixen, 2015; Porricelli et al., 2014).

It is intuitively reasonable to argue that employee $\mathrm{AC}$ could be a potential mediator of employee brand trust and BCT specific indirect effects on EBP in the proposed model. Although internal brand communications and brand-centred training initiatives are essential for translating abstract brand identity and intangible brand promises into brand reality to champion the brand (King \& Grace, 2008), it is not BCT and brand trust alone, but their successful integration with other organizational and branding aspects that drive superior EBP. Based on this mediation intuition, the following hypotheses are proposed:

H4: Employee affective brand commitment will mediate the effects of brand trust on employee brand performance.

H5: Employee affective brand commitment will mediate the effects of BCT on employee brand performance.

\subsection{Employee brand performance}

The significant role of employee performance in developing a successful and stronger service brand is well accepted and understood by academic scholars and business consultant (Foster et al., 2010; Xiong \& King, 2020) . IB literature suggests that organizational members are called service brand champions when their higher role brand-supportive performance bring the firms' brand meaning and brand messages to life through their meaningful service brand encounters with target customers (Wallace \& 
de Chernatony, 2009; Wallace et el., 2013). Employee brand performance (EBP) is crucial for enhancing a firm's performance and is also positively correlated to a brands' success (King \& Grace, 2012; Morhart et al., 2009; Podsakoff et al., 2000). Importantly, IBM adoption helps bridge the employees' cognitive brand knowledge (understanding) gap, and, in doing so, aligns customers' brand expectations with employee behaviors and subsequent service performance (King \& Grace, 2009). Buil et al. (2013) highlight that brand-related constructs could be critical drivers of enhancing EBP. However, IBM or internal marketing orientation literature about employee performance is inconclusive. Employee performance has been either descried or conceptualized in several different ways, such as brand market share or sales growth (Buil et al., 2009), BCB (Burmann \& Zeplin, 2005), brandcongruent behavior ((Löhndorf \& Diamantopoulos, 2014) and brand performance (Xiong \& King, 2015). Based on the brand management literature, employees can exhibit two types of brand-building behaviours that inform EBP, namely, in and extra-role behaviours (Burmann et al., 2008a; Liu et al., 2017; Morhart et al., 2009). In-role behaviour (part of the employees' formal job description) is commonly described in the literature as the ability of employees to meet the minimum service brand standards (e.g., employees' on-brand performance, as prescribed by the company based on their organisational roles and responsibilities as brand representatives (Morhart et al., 2009). Extra-role behaviour, on the other hand, is quite complicated as it involves an element of discretionary effort/or citizenship behaviour from employees, and, hence, it is difficult for service firms to regulate such employee extra-role behaviors and lay down service brand standards and delivery procedures. In other words, such employees' extra-role citizenship behaviors are not mandated or required by the service firm but is essential for brand success (Burmann \& Zeplin, 2005; Deluga, 1994; King \& Grace, 2009, 2012; Morhart et al., 2009; Podsakoff et al., 2000; Xiong \& King, 2018).

Previous studies on brand management that have investigated the antecedents and outcomes of IBM, such as EBP, are still inadequate (Punjaisri \& Wilson 2011; Santos-Vijande et al., 2013). Several IBM studies have taken an organisational viewpoint (e.g., management and brand consultants' perspective), and highlighted the role of IBM in influencing EBP. The employees' perspective in developing such desired brand performance has not been adequately focused by academics and practitioners alike (King et al., 2012; Xiong et al., 2015; Xiong \& King, 2020). Likewise, most companies focus and perspective on IBM is limited to only frontline employees (Saleem \& Iglesias, 2016). Such an approach can undermine the effectiveness of internal branding and raises serious concerns with its effect on a firm's brand performance (Iyer et al., 2018). In this regard, Xiong and King (2018) suggested it is a worthy effort to contribute to the existing IBM literature by understanding how employee brand performance is influenced (Xiong \& King, 2018). Past researches have offered mixed results regarding what effects EBP (King \& Grace, 2008; Punjaisri et al., 2009; Punjaisri \& Wilson, 2011). Employees' brand consistent behaviour (in-role and extra-role behaviour) incorporates the brand performance issues mainly to achieve some sort of "brand champions", as suggested by Ind (2004). However, in this study, EBP refers to the extent to which an employee performs his/her role, including the brand promise delivery, based on the brand standards (Punjaisri et al., 2009). Through on-brand performance (or inrole behavior) service firms can improve employees' delivery of brand-consistent messages. While extra-role behaviours may lead to higher customer satisfaction but can also lead to dissatisfaction as expectations are raised that are not always delivered by every employee. Hence, consistency is a critical element for brand reputation. In other words, to achieve desired brand performance, employees must perform their in-role behaviours as expected by the organizations and the target customers (Xiong \& King, 2018). 
Based on the theoretical foundations and proposed hypotheses, this study suggested a conceptual model.

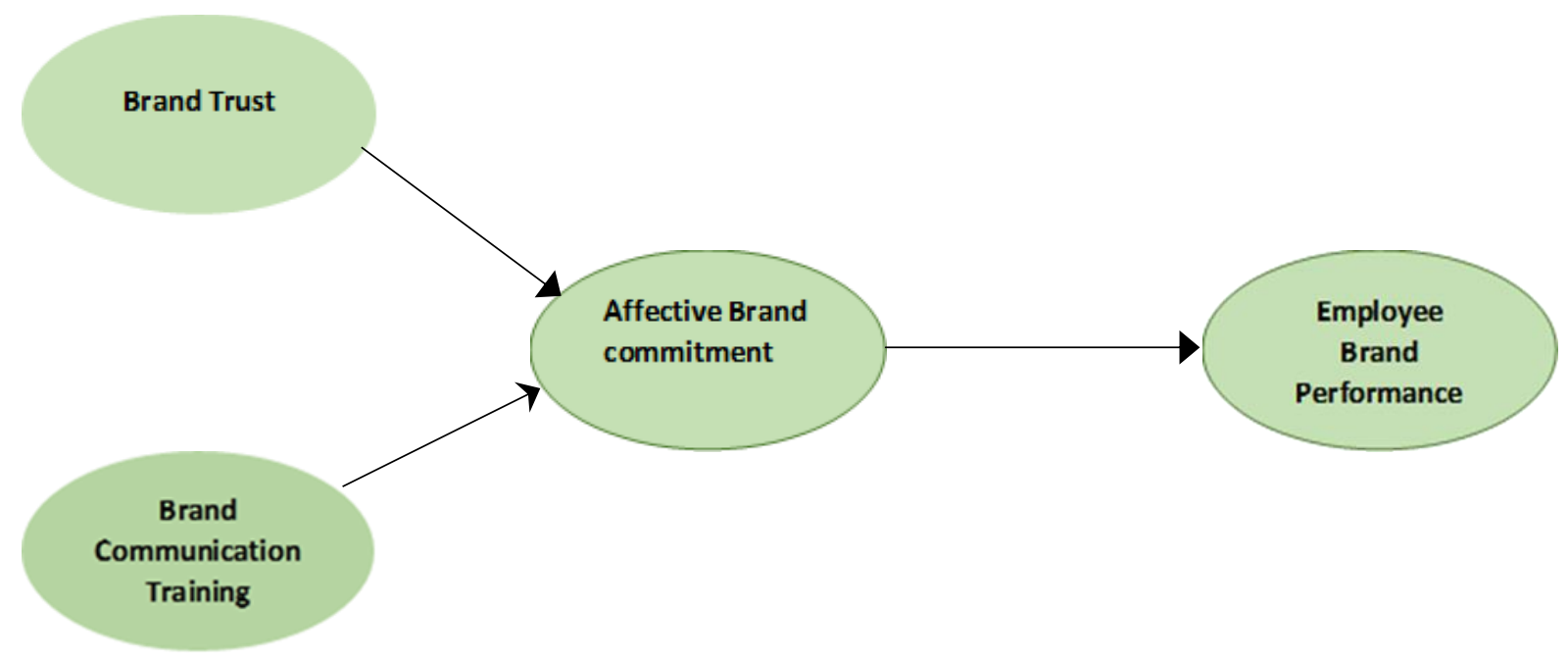

Source: Researcher's Conceptualization, 2020.

\section{Research method 3.1 Procedure}

Data was collected using a quantitative survey method. For this purpose, a constructed questionnaire was developed. A total of 750 questionnaires were distributed among bank employees, and 150 branches of five public banks in the Punjab province of Pakistan was considered based on nonprobability sampling. A cross-sectional survey was conducted from October 2017 to January 2018 in Punjab province, Pakistan (Punjab population: 110 million). Banks were randomly selected in different cities of Punjab (North Punjab, Central Punjab, and South Punjab). As a result, the public banks were selected from Punjab's big five cities. Besides, due to the nonavailability of population framework, and employing the strategy of Haque and Oino (2019), therefore, the sampling methods used were a combination of proportionate random sampling and convenience sampling techniques, for a sample selection of 426 public bank employees (managerial and non-managerial) from Punjab province, Pakistan. Banking sector of Pakistan is characterized by a diverse hierarchy of employees (Area heads, regional heads, branch managers, operational managers, customer relationship managers, branch service officers etc. The researcher contacted the branch managers to take permission to collect data. For carrying out this study, one hundred and fifty branches of 5 public banks were selected from Lahore, Pakistan. Out of 750 distributed questionnaires, a total of 496 were received. Of this number, 68 were unusable for various reasons, thus leaving 426 valid for study analysis with almost 56.8 percent response rate, which according to Sekaran and Bougie (2013) is a well-represented sample. The respondents included branch level employees covering lower and middle levels such as branch managers, operation managers and tellers etc. Employees, on the other hand, were sampled through proportionate convenience sampling guided by Johnson and Christensen's (2012) formula:

$\mathrm{ni}=(\mathrm{Ni} \times \mathrm{n}) / \mathrm{N}$

Where:

ni - Sample size

$\mathrm{Ni}$ - Employee population in each bank

$\mathrm{N}$ - Total population

n - Proposed Sample size (496 employees). 
Table 1: Sample size determination from each bank

\begin{tabular}{lccccc}
\hline $\begin{array}{l}\text { Public } \\
\text { Sector } \\
\text { Banks }\end{array}$ & $\begin{array}{c}\text { Employee } \\
\text { Population }\end{array}$ & $\begin{array}{c}\text { Employee } \\
\text { Sample }\end{array}$ & $\begin{array}{c}\text { No. of } \\
\text { Branches }\end{array}$ & $\begin{array}{c}\text { Selected } \\
\text { Branches }\end{array}$ & $\begin{array}{c}\text { Questionnaires } \\
\text { Distributed }\end{array}$ \\
\hline $\begin{array}{l}\text { National } \\
\text { Bank of } \\
\text { Pakistan }\end{array}$ & 15,519 & 283 & 1,422 & 90 & 390 \\
$\begin{array}{l}\text { First Women } \\
\text { Bank }\end{array}$ & 531 & 10 & 42 & 3 & 13 \\
$\begin{array}{l}\text { Sindh Bank } \\
\text { The Bank of }\end{array}$ & 1,985 & 36 & 250 & 17 & 73 \\
Punjab & 2,448 & 45 & 166 & 10 & 44 \\
$\begin{array}{l}\text { Bank of } \\
\text { Khyber }\end{array}$ & 6,739 & 122 & 480 & 30 & 130 \\
\hline Total & 27,222 & 496 & 2,360 & 150 & 650 \\
\hline
\end{tabular}

\subsection{Participants}

A total of 426 valid questionnaires were received at the end of the data collection period. Of the 426 bank employees, males represented the majority of the sample, $71.6 \%$ (305) were male. Regarding age, the most significant representation was $39.4 \%$ (168) respondents were within the age group of 31-40 years old, while $29.8 \%$ (127) respondents were relatively young and in the age range of 21-30 years old. With regard to educational attainment, about half of the respondents 50\% (213) had their master's degree, while 20\% (85) had their bachelor's degree and only $17.1 \%$ (73) had their College certificate. Meanwhile, the remaining 8\% (34) had a diploma in banking, and only 4.9\% (21) possessed a PhD's degree. Lastly, in terms of department and job positions, $23 \%$ (98) of the respondents were in the management positions, $22.1 \%$ (94) were in the operations department, followed by $18.1 \%$ (77) were in accounts/finance, and $11.3 \%$ (48) were in the HR department. Likewise, $11.3 \%$ (48) were in consumer banking. Meanwhile, employees and staff who represented various departments and functions were accounted for $25.58 \%$ (109) were in sales \& marketing and credit \& advances department, as listed in table 2.

Table 2: Demographics of the respondents

\begin{tabular}{lcc}
\hline Profile & Frequency $(\mathbf{n = 4 2 6})$ & Percentage (\%) \\
\hline Age $21-30$ & 127 & 29.8 \\
$31-40$ & 168 & 39.45 \\
$\quad$ above 40 & 131 & 30.75 \\
Gender & & 40.3 \\
$\quad$ Male & 305 & 28.4 \\
Female & 121 &
\end{tabular}


Education Level College

Graduate

Master

$\mathrm{PhD}$

Diploma in Banking

\section{Departments}

Accounting \& Finance $\quad 77$

Human Resource (HR)

Operations

\subsection{Measures}

The scale measurement items were derived from past studies demonstrating good reliability and validity. All constructs were measured on five-point Likert scales to measure the attitudes and behaviors of respondents. All four-item scales taken directly from the work of Chaudhuri and Holbrook (2001). The operationalization of brand trust construct was based on three qualities of trust that are reliability, honesty, and safety. Construct trust is measured by the ability of the brand to deliver on its promises. A sample item was "I trust this bank (brand)". All four antecedents of BCT (TR, BF, GM and Ort) were measured using an 11-item scale which was originally developed by Punjaisri and Wilson (2011) to measure the extent to which training and internal communications mechanism is capable of encouraging employee 'on brand behaviours to ensure successful delivery of the brand promise. Importantly, the scope of brand training in this study is restricted to include only those aspects of training that facilitate internal branding outcomes and not all the kinds of employee training. A sample item was "Training programs give me appropriate skills in relation to delivering brand promise". Construct BC was evaluated using a 9-item scale again taken directly from the study of Kimpakorn \& Tocquer, (2009). The measures of employee BC included items relating to identification, involvement, and loyalty. A sample item was "for me this is the best of all possible banks (brands) to work for". Finally, in terms of the dependent variable, EBP was assessed using the 5-item scale, again taken directly from Punjaisri and Wilson's (2011) study. The operationalization of construct EBP in this study was aimed at measuring the extent to which an organizational member performs his/her role in relation to the brand promise delivery based on the service standards in which the brand values are embedded. The Likert scales ranging from $1=$ Strongly disagreed, and 5=Strongly agreed have been used table 3 .

\section{Table 3: Construct and scale items}

\begin{tabular}{llc}
\hline Construct & Scale & No of items \\
\hline $\begin{array}{ll}\text { Brand communication } \\
\& \text { training }\end{array}$ & $\begin{array}{l}\text { The brand standards are constantly reinforced during the } \\
\text { briefings } \\
\text { The brand promise is constantly reinforced during the } \\
\text { briefings } \\
\text { This bank informs me in an excellent way about things that is } \\
\text { relevant to my work }\end{array}$
\end{tabular}


I feel encouraged to come up with new suggestions of how to do things

Orientation program triggers my inspirations to appropriately fulfil the brand promise deliver

I like the brand manuals of this bank (brand)

During the group meetings, I am clearly informed of the brand mission

I clearly understand my role in relation to the brand mission after attending the group meetings

Briefings contain all essential information for me to provide services according to brand expectations

Training programs gives me appropriate skills in relation to delivering brand promise

I am usually attracted towards messages made of colorful materials

Brand trust

I trust this bank (brand)

I rely on this bank (brand)

This bank is an honest brand

This bank is a safe brand

Brand commitment

I usually tell my friends that this a great bank (brand) to work for

I am proud to tell others that I am part of this bank (brand)

For me this is the best of all possible banks (brands) to work for

I am extremely happy that I chose to work for this bank (brand) over others I was considering

I really care about this bank (brand)

I would accept almost any type of job assignment to keep working for this bank (brand)

I am willing to put in a great deal of effort beyond that normally expected to help this bank (brand) to be successful

With this bank (brand), I obtain what I look for in my work life

It would take very little to cause me to leave this bank (brand)

Brand performance The quality level of my services meets the brand standards of this bank (brand)

Sometimes, I neglect aspects of the job I am supposed to perform (R)

I can successfully fulfil responsibilities specified in my job description 
I effectively fulfil the promise that bank (brand) has with its customers

I always handle customer's specific requests within a

standard set for the bank (brand)

\section{Results \\ 4.1 Preliminary analysis}

A few initial tests were performed before the inferential analysis. The online tool Web Power was used to test the multivariate normality of the data (Peng \& Lai, 2012). The calculated Mardia's normalized multivariate kurtosis was 14.42 , and skewness coefficient for this study was 32.27. As the p-values were less than $0.05(\mathrm{p}=0)$, suggesting a potential multivariate normality issue in the study data. To remedy this situation, the researchers make uses of bootstrapping technique (500 bootstrap samples with biascorrected confidence intervals [CIs] at 90\%) in evaluating both measurement and structural models through Smart PLS 3.2.7. PLS-SEM is a useful option, especially when the data is non-normal (Hair et al., 2017). implying that, PLS-SEM has no distribution and sampling assumption due to its nonparametric characteristic (Vinzi et al., 2010). Additionally, business and management studies use this technique extensively (Hair et al., 2016; Henseler et al., 2015). Common Method Bias (CMB) was examined through Harman's single-factor test by exposing all items to an Exploratory Factor Analysis (EFA). Six factors have emerged, and a maximum variance that is explained by a single factor was only $32.16 \%$, which is less than half of the variance. Thus, it can be concluded that the data in the study is not suffered from CMB bias. Achieving a good measurement model, to test the strength of relationships among latent variables structural equation model using PLS-SEM approach was used.

\subsection{Evaluation of Measurement model}

PLS-SEM was used for this study because the data was not normally distributed. Besides, the study is based on a second-order construct (e.g., BCT is used as a second-order reflective construct in this study). The study data were examined in two stages. The outer model was measured in the first step, where researchers checked the reliabilities and validities of the latent variable constructs using outer loadings, Composite Reliabilities (CR), Average Variance Extracted (AVE), and Rho_A values. The direct and indirect relationships among variables were measured in the second stage (also known as the inner model in PLS-SEM), where the structural model was assessed. In the first stage, confirmatory factor analysis (CFA) was conducted to test the measurement model and importantly, to determine the reliability and validity for the scale items. Table 4 explains the outer model values, including the outer loadings, AVE, CR, and Rho_A values. The recommended threshold level for the standardized loading value is 0.70 , as proposed by Hair et al. (2016). Adhering to the standards, few items were deleted from the proposed model. According to table 4, all standardized loading values are statistically significant and above .70. Additionally, the Composite Reliability (CR) of the constructs is also reported as it is a superior measure of scale reliability than Cronbach's alpha values according to Bagozzi and Yi (1980) and they are all above 0.85, meaning that comfortably above the suggested level of 0.6 (Hair et al., 2006). All Average Variance Extracted (AVE) values are also above 0.5, that is more than half of variance in all constructs are adequately explained, hence convergent validity is also supported. Consequently, the study assumed that all items are valid and reliable measures of employee brand performance construct (outcome variable of the study). Hence, the study adequately demonstrated both validity and reliability for further analysis (Henseler et al., 2009). In addition to that, the discriminant validity was assessed by using the Heterotrait-Monotrait (HTMT) ratio (Henseler et al., 2015). Table 5 shows the HTMT ratio values. All the values are lower than 0.90 , which confirms discriminant validity. 
Table 4: Measurement model

\begin{tabular}{|c|c|c|c|c|c|c|}
\hline $\begin{array}{l}\text { 1st Order } \\
\text { constructs }\end{array}$ & $\begin{array}{l}\text { 2nd Order } \\
\text { Constructs }\end{array}$ & Items & Loadings & $\begin{array}{l}\text { Composite } \\
\text { Reliability }\end{array}$ & Rho_A & $\begin{array}{c}\text { Average } \\
\text { Variance } \\
\text { Extracted } \\
\text { (AVE) }\end{array}$ \\
\hline \multirow{7}{*}{$\begin{array}{l}\text { Brand } \\
\text { Commitment }\end{array}$} & & $\mathrm{BC} 1$ & 0.804 & 0.879 & 0.845 & 0.510 \\
\hline & & $\mathrm{BC} 2$ & 0.789 & & & \\
\hline & & $\mathrm{BC} 3$ & 0.713 & & & \\
\hline & & BC6 & 0.668 & & & \\
\hline & & $\mathrm{BC} 7$ & 0.640 & & & \\
\hline & & $\mathrm{BC} 8$ & 0.713 & & & \\
\hline & & BC9 & 0.657 & & & \\
\hline Brand & & BP1 & 0.663 & 0.823 & 0.719 & 0.538 \\
\hline \multirow[t]{3}{*}{ Performance } & & BP3 & 0.802 & & & \\
\hline & & BP4 & 0.763 & & & \\
\hline & & BP5 & 0.698 & & & \\
\hline \multirow[t]{4}{*}{ Brand Trust } & & BT1 & 0.849 & 0.876 & 0.819 & 0.639 \\
\hline & & BT2 & 0.825 & & & \\
\hline & & BT3 & 0.778 & & & \\
\hline & & BT4 & 0.741 & & & \\
\hline \multirow[t]{4}{*}{ Training } & & TR1 & 0.771 & 0.861 & & 0.526 \\
\hline & & TR2 & 0.673 & & & \\
\hline & & TR3 & 0.710 & & & \\
\hline & & TR4 & 0.744 & & & \\
\hline \multirow[t]{2}{*}{ Orientation } & & OR5 & 0.780 & 0.761 & & 0.614 \\
\hline & & OR6 & 0.787 & & & \\
\hline \multirow[t]{2}{*}{ Group Meeting } & & GM7 & 0.853 & 0.832 & & 0.712 \\
\hline & & GM8 & 0.835 & & & \\
\hline \multirow[t]{5}{*}{ Briefing } & & BF9 & 0.850 & 0.802 & & 0.578 \\
\hline & & BF10 & 0.785 & & & \\
\hline & & BF11 & 0.628 & & & \\
\hline & $\mathrm{BCT}$ & & & 0.909 & 0.872 & 0.715 \\
\hline & & TR & 0.859 & & & \\
\hline
\end{tabular}




$\begin{array}{ll}\text { ORT } & 0.838 \\ \text { GM } & 0.798 \\ \text { BF } & 0.884\end{array}$

Note: 2 items are deleted from brand commitment (BC) construct, and 1 item is deleted from brand performance (BP) construct; TR (Training), ORT (Orientation), GM (Group Meeting), BF (Briefing) \& BCT (Brand Communication Training).

Table 5: HTMT Criterion

$\begin{array}{llll}1 & 2 & 3 & 4\end{array}$

1. Brand Commitment

2. Brand Communication Training

0.842

3. Brand Performance

0.831

0.733

4. Brand Trust

0.866

0.766

0.707

\subsection{Measurement of structural model (results)}

In addition to path coefficient (t-statistics) was run to analysis for direct relationships among variables, specific indirect effects were also performed to test the mediation effects as suggested in the conceptual model, along with a bias-corrected bootstrap method to produce confidence intervals for statistical inference in mediation analysis (MacKinnon et al., 215) method. Employee affective brand commitment was positively influenced by their brand trust $(\beta=0.436, t=10.601, p=0.000)$ in support of H1. Meaning that as employee trust to the brand enhanced, their commitment to the brand also increased. Likewise, brand communication training (BCT) showed a significant direct influence on affective brand commitment $(\beta=0.442, \mathrm{t}=10.962, \mathrm{p}=0.000)$, hence, $\mathrm{H} 2$ is also accepted. Also supporting H3, as suggested by the study, that is affective brand commitment is found to have a significant positive impact on employee brand performance $(\beta=0.644, \mathrm{t}=17.953, \mathrm{p}=0.000)$; hence, $\mathrm{H} 3$ is also supported. As employees commitment to the company and its brand increased, they were more likely to exhibit brand supporting behaviors that further enhance their brand performance.

To test $\mathrm{H} 4$ and $\mathrm{H} 5$, regarding the hypothesized mediating role of affective brand commitment among brand trust and brand communication training and EBP, researchers adopted Preacher and Hayes's (2008) method. The results indicate that brand trust $(\beta=0.281, \mathrm{t}=9.623, \mathrm{LLCI}=0.229, \mathrm{ULCI}=0.341)$ and brand communication and training $(\beta=0.285, \mathrm{t}=8.499$, LLCI $=0.231$, ULCI $=0.328)$ have an indirect effect on EBP through employee affective brand commitment. Moreover, since zero was absent from the 99\% bias-corrected and accelerated bootstrap confidence interval, therefore, the indirect path is significant, and suggest a partial mediation effect. Thus, all the direct and indirect effects were found to positively affected employees brand performance.

Table 6: Direct and indirect effects

\begin{tabular}{llcccccccc}
\hline & Direct Effect & Beta & $\begin{array}{c}\text { Confidence } \\
\text { Interval }\end{array}$ & SD & $\begin{array}{c}\mathbf{t}- \\
\text { value }\end{array}$ & $\mathbf{f 2}$ & $\mathbf{Q}^{\mathbf{2}}$ & $\mathbf{R}^{\mathbf{2}}$ & Decision \\
\hline $\mathrm{H} 1$ & $\mathrm{BT} \rightarrow \mathrm{BC}$ & 0.436 & {$[0.678,0.756]$} & 0.042 & 10.409 & 0.303 & 0.319 & 0.634 & $\mathrm{~S}$ \\
$\mathrm{H} 2$ & $\mathrm{BCT} \rightarrow \mathrm{BC}$ & 0.442 & {$[0.675,0.765]$} & 0.041 & 10.673 & 0.311 & 0.319 & 0.634 & $\mathrm{~S}$ \\
$\mathrm{H} 3$ & $\mathrm{BC} \rightarrow \mathrm{BP}$ & 0.644 & {$[0.579,0.699]$} & 0.036 & 17.923 & 0.708 & 0.218 & 0.415 & $\mathrm{~S}$ \\
\hline & Indirect Effect & Beta & $\begin{array}{c}\text { Confidence } \\
\text { Interval }\end{array}$ & SD & $\begin{array}{c}\text { t- } \\
\text { value }\end{array}$ & & & & Decision \\
\hline $\mathrm{H} 4$ & $\mathrm{BT} \rightarrow \mathrm{BC} \rightarrow \mathrm{BP}$ & 0.281 & {$[0.467,0.609]$} & 0.029 & 9.519 & & & & $\mathrm{~S}$ \\
$\mathrm{H} 5$ & $\mathrm{BCT} \rightarrow \mathrm{BC} \rightarrow \mathrm{BP}$ & 0.285 & {$[0.503,0.646]$} & 0.034 & 8.397 & & & & $\mathrm{~S}$ \\
\hline
\end{tabular}


Note: Direct Effect - one-tailed test, Confidence Interval (5\%-95\%); Indirect Effect - one-tailed test; Brand Trust (BT), Brand Commitment (BC), Brand Communication Training (BCT) \& Brand Performance (BP); Decision: Not Supported (NS), Supported (S).

\subsection{Importance-Performance Map Analysis}

The importance-performance matrix analysis (IPMA) categorizes the latent variables (predictors) into relatively high to low by importance and performance (Chin, 2010). IPMA supports the identification of a possible area of improvements that requires considerable focus from managers and practitioners. IPMA analysis is based on the total effect of the rescaled variables scores in the unstandardized arrangement (Ringle \& Sarstedt, 2016). Rescaling develops each latent variable score that is between 0 and 100 . The mean value of the latent variable score represents the performance of the latent variable, where 0 represents the least significant performance, and 100 represents the most important one in the performance of the endogenous variable (Hair et al., 2019). Table 7 displays the effects of the importance-performance matrix. There is a slight variation in the performance of all the latent variables. The results indicate that $\mathrm{BT}$ is the most critical component in the performance of EBP (76.027), BC (74.148), and BCT (66.738). For the total effect size of EBP, the most important factor is BC (0.644), followed by BCT (0.285), and BT (0.281) is the least important variable. This means, service firms and other businesses need to strengthen further the commitment of employees to the brand as there is still there is space to increase the performance.

Table 7. Importance-Performance Matrix

Target Construct

EBP

\begin{tabular}{ccc}
\hline Variables & Total Effect & Performance \\
\hline BC & 0.644 & 74.148 \\
BCT & 0.285 & 66.738 \\
BT & 0.281 & 76.027 \\
\hline
\end{tabular}

Note: Brand Trust (BT), Brand Commitment (BC), Brand Communication Training (BCT) \& Brand Performance (BP).

\section{Figure 1: Results of the structural model}

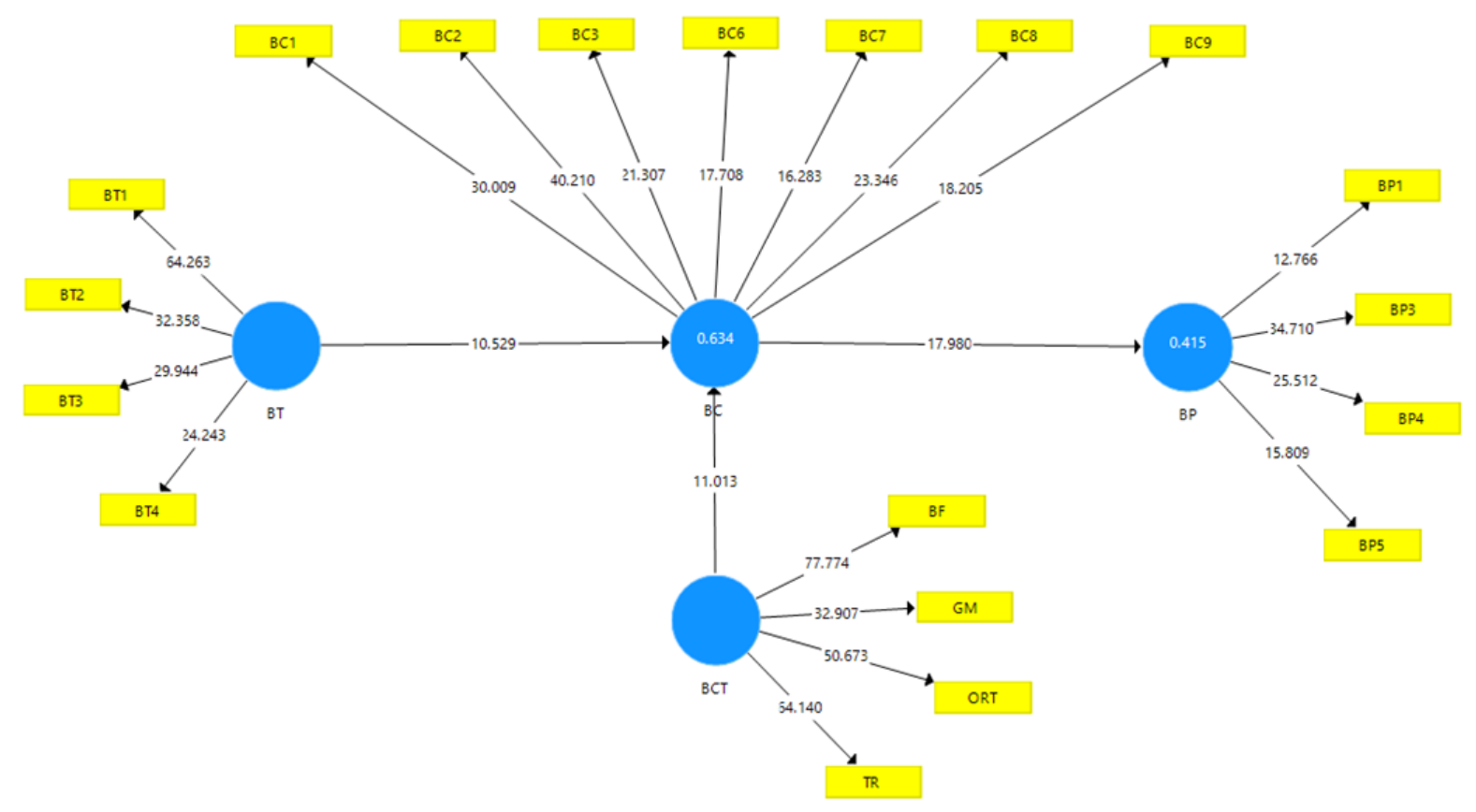




\section{Discussion}

From the bank employee's perspective, this paper aimed to gain further insight and a better understanding of the brand trust and corporate brand communication and training (BCT) one of the key dimensions of IBM, described in this study as a formal organizational support mechanism or proposed as internal branding tools by Punjaisri \& Wilson (2011), by analyzing the effect of these two constructs on employee brand performance (EBP) in public sector banks of Pakistan. The findings affirm the relevance of these two key constructs, especially in the IBM context, given their ability to enhance employees' affective brand commitment to living the company brand (a behavioral and psychological mechanism) that eventually strengthens and advancing employees' brand performance. Findings further indicate that trust and internal communications and training fosters the allegiance of banking staff to their organization (brand) in the form of affective commitment that indicates bank employees acted in a brand supportive manner. Earlier studies in the literature have also underlined the considerable influence of the higher level of employee commitment as a critical success factor and sustainable differentiation for the corporate brand (Balmer, 2001). A high level of affective commitment can be accomplished through various means; however, the nature and strength of the causal association found in this research confirm that brand trust and BCT are crucial antecedents to create this cognitive and affective bond between service staff and the bank. Since EBP comprises of both in and extra-role brand supporting behaviors, continuous and on-time support from the banking organizations in the form of formal organizational support such as internal communications and training is likely to inform and enhance EBP.

Additionally, the indirect effect via employee affective commitment on the proposed relation between brand trust and BCT and EBP is hypothesized and empirically tested to provide a better explanation for the proposed relationship in the context of the banking sector, and particularly in a developing country context like Pakistan, where internal branding practices/ or strategies remain under-theorized and poorly executed in practice. Moreover, Pakistani culture is entirely different from the Arab or Western cultural environments, where most studies on employee performance and commitment are supposedly carried out. Through a sample of bank employees, this paper generates important results.

The study also uncovers some interesting conclusions involving the association among employees' affective commitment and EBP. First, contrary to some earlier studies, which reported a nonexistent or only a weak association among the two (see Punjaisri \& Wilson, 2011 study) variables, earlier inquires have found that affective commitment positively impacts EBP (Burmann et al., 2009; de Chernatony et al., 2003; Kimpakorn \& Tocquer, 2010). Additionally, the study findings demonstrate that affective commitment positively impacts the way a bank staff carries out his/her role based on the brand standards defined (in-role activities or on-brand performance). Based on this study's empirical findings, it is appropriate to suggest bank managers should nurture and develop favorable employees' pro-brand behavior and attitude that create a sustainable commitment to the organisation and its brand, which in turn affect their brand performance as desired by the service organizations.

Second, the findings of the study revealed that brand trust exerts significant and positive effects on the affective commitment of bank employees. This direct effect of brand trust on employee affective brand commitment concur and are in line with the commitment-trust theory of marketing relationships introduced by Morgan and Hunt (1994) and studies by Chaudhuri and Holbrook (2002), Erkmen et al. (2017) and Kim and Yi (2018).

Thirdly, the study results also showed that brand trust among employees is significantly and positively linked to the BCB or EBP (Erkmen \& Hancer, 2015). It implies that as employee brand trust is enhanced, their brand performance is also improved. That is because if employees strongly believe and show confidence in their company's brand reliability and integrity, they will accept the company brand in their hearts and minds and deliver superior brand-aligned experience, and that should lead to enhanced service excellence and stronger service brands (Foster et al., 2010). In addition to that, the association between internal brand communications \& training (BCT) and employee affective brand commitment is consistent with several past studies (e.g., Burmann et al., 2009; de Chernatony \& SegalHorn, 2003; Muhammad et al., 2019; Porricelli et al., 2014; Sharma \& Kamalanabhan, 2012). Past 
researches have also showed a significant role of employee BCT in encouraging EBP (Buil et al., 2016; Burmann et al., 2009; Burmann \& König, 2011; Muhammad et al., 2019; Morhart et al., 2009; Punjaisri \& Wilson, 2011; Terglav et al., 2016).

Fourthly, the findings of the quantitative survey suggested that effective perceived organizational support (POS) mechanism or formal organizational interventions (vertical) such as internal brand communications and brand-centred training programs have a positive effect on the commitment of bank employees (willingness to deliver the desired brand promise), and significantly contribute to reducing the service performance delivery gap by accepting and internalizing core brand values and brand messages, that enable public banks to achieve distinctive and sustainable brand differentiation by communication and displaying more non-functional/or emotional characteristics of their corporate brands through their service staff's brand supporting attitude and performance (Garas et al., 2018; King \& Grace, 2012). This finding is also consistent with Harris and de Chernatony's (2001) suggestions that service companies and other businesses take effective measures to ensure that service staffs, who are the primary informants of customer's brand-specific information, communicators, and deliverers of the corporate brand identity, and more importantly consistently reflect and display the brand's desired identity and brand values through their brand supporting behaviors in order to keep the current company image and credibility.

\subsection{Theoretical implications}

The current study expands the extant brand management literature on the positive effects of internal branding strategies/practices on the attitudes and behaviours of employees working in the banking and other services industries. Although, past researchers have tried to comprehend what affects employee brand performance (Burmann et al., 2009; Punjaisri \& Wilson, 2007, 2011; Punjaisri et al., 2009; Shaari et al., 2015). Their work focused primarily on the role of employee AC to understanding EBP behaviour. To address this specific research void, the current study includes trust and BCT constructs to better explain and offer empirical evidence of its joint effect on EBP in Pakistan's banking sector. This work has expanded the existing theories in the literature on IBM by incorporating the commitment-trust theory of relationships (Hunt \& Morgan, 1994) and perceived organizational support (POS) (Eisenberger et al. 1990) theories and argues that IBM is positively connected to the EBP as determined by the degree to which they deliver on the brand promise as engendered in company brand standards (or brand expectations) which encourage more in-role brand-building behaviors. That is because in-role behaviours as set by brand standards are the critical requirement to deliver a consistent brand promise to the customer. On the other hand, employee extra-role behaviours (volitional behavior) may lead to higher satisfaction. However, they can also lead to dissatisfaction as expectations are raised that are not always delivered by every member of the staff.

Internal marketing research suggests that if internal stakeholders perceive the that the brand as important and related to their career development and company (brand) success (Xiong et al., 2013), they are likely to build brand trust and are cognitively and affectively attached to the company's brand. In addition, they are motivated to perform better by enhancing their in and extra-role practices (e.g., brand development and helping behavior) that are favorable to the organization, and are thus affectively engaged to upholding the company's brand commitment and understand the company's success and failure as their own (Punjaisri \& Wilson, 2007). Studies which have explored the positive effects of POS (e.g., internal brand communications and training) on EBP, especially in the service industries are scare (Chiang et al., 2010; Faulkner \& Patiar, 1997; Xiong \& King, 2018). Building on the POS, this study confirms the effect of POS in IBM context, that is, when employees perceive adequate formal organizational support in the form of internal communication and brand training (BCT), they are more likely to develop appropriate brand understanding and deliver on the brand promise. The findings of this study further reinforce the views expressed by Miles and Mangold (2004) on the importance of formal brand knowledge (brand-related information) dissemination (similar to intellectual-emotional-buy-in) that can lead to a better understanding of the company brand by employees, in turn, may positively affect their brand performance. More importantly, to improve employee service performance and their ability to serve customers better, employees should rely more 
on formal organizational sources of brand knowledge dissemination than on informal sources of information, for instance, support from peers or co-workers etc. (Xiong \& King, 2018). In other words, service staff who have the appropriate and sufficient knowledge of the brand obtained through formal communication channels of the service firm, are more likely to better understand their role and responsibility in the success of the brand and deliver the expected brand promise (Ambler 2003; King $\&$ Grace, 2010). In comparison, positive effects of formal brand knowledge dissemination on employee brand performance, where there is no clear guidance and adequate perceived organizational support (POS) system to disseminate consistent, relevant and accurate internal communication of brand knowledge dissemination and to regulate EBP, the consequences are that bank employees may engage in inappropriate behaviors on their misinterpretation of what the brand actually represents and stands for. As a result, their good intentions, and brand-supporting behaviors to help and advance the bank brand could fail, and thus, the performance of their brand delivery may unintendedly harm the credibility and image of the company brand. (Xiong \& King, 2018).

\subsection{Practical implications}

The effectiveness of internal and external brand-building efforts is informed by a successful execution of IBM, ensuring employee trust, dissemination of appropriate brand knowledge, training, and affective commitment to the company brand and improving employee's brand awareness and brand competency of how to deliver more than good service. Surprisingly, the efficacy of IBM, many service providers and other companies ignore this critical dimension of their overall corporate business strategy that is profoundly embedded in the brand and corporate success. Empirical results from this research paper offer a number of managerial implications for key decision makers including policy makers, brand managers and other bank executives in Pakistan's banking sector who wish to comprehend how employee brand-aligned performance affects corporate brand identity and brand success. Based on the above results, banks may stress the affective commitment (AC) of employees to improve their brand performance. Furthermore, managing employee AC is a strategically critical challenge for Pakistan's banking sector.

First of all, IBM should be aligned and fully integrated into the overall corporate business and branding strategy to efficiently realize company and branding goals (Balmer \& Greyser, 2006; Punjaisri \& Wilson, 2011). Second, this paper argues that the introducing of an effective IBM that guides and informs all strategic corporate business decisions and operations within an enterprise, will also ensure that internal brand communications and training programs are aligned with the actual corporate objectives, priorities, values, products/or services will also have a positive impact on employee affective brand commitment and EBP (Garas, 2019; Punjaisri \& Wilson, 2011).

Dimensions of brand-centred training such as orientation, group meetings, briefings and development activities can ensure that bank staff have appropriate product/brand knowledge, skill, expertise, and ability to deliver an excellent brand experience in ways consistent with its corporate brand identity and promise. More specifically, bank employees particularly customer-facing staff deliver on the actual brand promise not only because the brand standards or brand expectations demand it, but also because they are affectively and cognitively committed to making the corporate brand a success. Once IBM is in operation, evaluating the performance of bank employees, particularly, customer-facing staff (e.g., customer service providers and cashiers/tellers), company driven IBM activities make it essential to reconsider the metrics used to access and measure the performance of bank staff (Garas et al., 2019). In particular, the performance of bank employees can be assessed more objectively by bank management using an internal performance appraisal system that integrates both out-put efficiency (e.g., sales/revenue targets) and employee behavioral metrics; however, more emphasis should be placed on later to fulfill their crucial role in delivering service quality and brand-aligned customer experience, in order to encourage EBP (Garas et al., 2019; Papasolomou \&Vrontis, 2006; Sujchaphong et al., 2020). These company driven formal internal mechanisms/or positive internal interventions will enable bank management to establish and foster a strong service attitude (mindset) among service staff to distinguish the corporate brand. 
Lastly, IBM tools such as brand-centred training and internal communication practices may be customized to respond effectively to mee the product or service knowledge needs of bank employees working in different divisions or belonging to different cohorts. While several aspects of cognitive brand knowledge (understanding) are either tacit or implicit, therefore, managers need to facilitate employee brand knowledge learning by adopting specific brand-specific training programs, like workshops/seminars, mentorship programs, brand tool kit, and smart communications platforms/apps in particular should help and encourage service staff to develop good service attitudes, brand skill, broad and wide-ranging knowledge and awareness of financial products, brand competency, which in effect enhances their brand-supporting behavior in providing consistent brand experience (Buil et al., 2016; Muhammad et al., 2019; Piehler et al., 2016; Xiong et al., 2019). Conversely, simply provide brand knowledge (information) to the bank employees or allowing them to engage in interactive brand development sessions, do not ensure that they have correctly understood internalized and learned what the company expects regarding satisfactory brand-aligned promise delivery (Xiong et al., 2019). In addition, bank managers must track the level of brand knowledge, brand awareness, and brand competence of their service personnel on an ongoing basis to ensure that they are prepared to comply with the brand standards strictly laid down by the company they work for. In summary, the findings of this study suggest banks need to concentrate on the success of their employees for desirable brand identity and image.

In general, improving the effectiveness of corporate brand performance, particularly in banking and other financial institutions, calls for IBM strategy that incorporates among other things, clear, transparent internal communications of corporate values, in combination with various dimensions of brand-centred training programs discussed above, which are expected to play a central role in enhancing employee brand performance in banking other service institutions. Although employee cognitive brand knowledge is an essential requirement for employee brand performance, however, affective brand commitment ensures the employee brand performance to remain consistent in the long run. So while brand understanding is essential to behave brand-consistent (on-brand performance), affective brand commitment (which takes longer to build) is essential for such behaviour to be persistent over time.

\subsection{Limitations and suggestions for future research}

In addition to the important results, this study also illustrates some issues and shortcomings which can be viewed as opportunities for future research projects. First of all, a cross-sectional research design was used for data collection. Longitudinal research may be beneficial if the latent variables, primarily linked to employee brand performance that discussed less in past studies, are further confirmed by casual associations. Second, all latent variables included in the current study were assessed through the self-reported constructs of bank staff; therefore, future surveys should measure these latent variables constructs through supervisor or manager rated version for each measure. Third, the sampling frame of public bank employees could not be reached. Therefore, a convenience sampling approach for the collection of the data was used. The results and conclusions of the current research are based on the data from only public sector banks and hence the findings cannot be generalized for this particular sector.

Future research also should check the relationships suggested in this article with other high-customer contact services industries like telecommunications, insurance firms, airlines and other countries and cities that require easy access to sampling frames and use probability sample techniques to analyze the contextual differences. This study integrating only an affective commitment to better understand employee success in the workplace, one of the dimensions of Allen and Meyer's (1990) threecomponent commitment model. Other types of commitment that are normative and continuous could also better explain the commitment of employees to the organization's brand. Hence, brand commitment construct may be explored further in detail for different dimensions of commitment to provide more useful insights how these additional dimensions of commitment can inform employee brand performance and turn employees into brand champions (Lohndorf \& Diamantopoulos, 2014; Garas et al., 2018). Lastly, this research looks at internal processes for the implementation of an 
internal branding initiative, but it is worth examining external approaches such as customers' ideas about internal branding.

\section{References}

Ambler, T., \& Styles, C. (1996). Brand development versus new product development: towards process model of extension decisions. Marketing Intelligence \& Planning, 14 (7), 10-19.

Balmer, J. M. T., Harris, F., \& de Chernatony, L. (2001). Corporate branding and corporate brand performance. European Journal of marketing, 5(3/4), 441-456

Balmer, J. M. T., \& Greyser, S. A. (2006). Corporate marketing: Integrating corporate identity, corporate branding, corporate communications, corporate image and corporate reputation. European Journal of Marketing, 40(7/8), 730-741.

Berry, L. L. (2000). Cultivating service brand equity. Journal of the Academy of marketing Science, 28(1), 128-137.

Buil, I., Catalán, S., \& Martínez, E. (2016). The importance of corporate brand identity in business management: An application to the UK banking sector. BRQ Business Research Quarterly, 19(1), 3-12.

Buil, I., Martínez, E., \& Matute, J. (2019). Transformational leadership and employee performance: The role of identification, engagement and proactive personality. International Journal of Hospitality Management, 77, 64-75.

Burmann, C., \& Zeplin, S. (2005). Building brand commitment: A behavioral approach to internal brand management. Journal of brand management, 12(4), 279-300.

Burmann, C., Jost-Benz, M., \& Riley, N. (2009a). Towards an identity-based brand equity model. Journal of Business research, 62(3), 390-397.

Burmann, C., Zeplin, S., \& Riley, N. (2009b). Key determinants of internal brand management success: An exploratory empirical analysis. Journal of brand management, 16(4), 264-284.

Burmann, C., \& König, V. (2011). Does internal brand management really drive brand commitment in shared-service call centers? Journal of brand management, 18(6), 374-393.

Chang, A., Chiang, H. H., \& Han, T. S. (2012). A multilevel investigation of relationships among brand-centered HRM, brand psychological ownership, brand citizenship behaviors, and customer satisfaction. European Journal of Marketing, 46(5), 626-662.

Chan-Olmsted, S. M., \& Kim, Y. (2001). Perceptions of branding among television station managers: An exploratory analysis. Journal of broadcasting \& electronic media, 45(1), 75-91.

Chen, P. K., \& Huang, C. E. (2012). Brands and consumer behavior. Social Behavior and Personality: An International Journal, 40(1), 105-114.

Chiang, C. F., \& Wang, Y. Y. (2012). The effects of transactional and transformational leadership on organizational commitment in hotels: The mediating effect of trust. Journal of Hotel and Business Management, 1(1), 1-11.

Chiang, F. F., Birtch, T. A., \& Kwan, H. K. (2010). The moderating roles of job control and work-life balance practices on employee stress in the hotel and catering industry. International Journal of Hospitality Management, 29(1), 25-32.

Chin, W. W. (2010). How to write up and report PLS analyses. In Handbook of partial least squares. Springer, Berlin, Heidelberg, 655-690.

Chaudhuri, A., \& Holbrook, M. B. (2001). The chain of effects from brand trust and brand affect to brand performance: the role of brand loyalty. Journal of marketing, 65(2), 81-93.

Chaudhuri, A., \& Holbrook, M. B. (2002). Product-class effects on brand commitment and brand outcomes: The role of brand trust and brand affect. Journal of Brand Management, 10(1), 3358.

De Chernatony, L., \& Cottam, S. (2006). Internal brand factors driving successful financial services brands. European Journal of Marketing, 40, 611-633.

Delgado-Ballester, E., \& Munuera-Alemán, J. L. (2001). Brand trust in the context of consumer loyalty. European Journal of marketing, 35(11/12), 1238-1258.

Dirks, K. T., \& Ferrin, D. L. (2001). The role of trust in organizational settings. Organization science, 12(4), 450-467. 
Dirks, K. T., \& Ferrin, D. L. (2002). Trust in leadership: Meta-analytic findings and implications for research and practice. Journal of Applied Psychology, 87(4), 611-628.

Dhiman, P., \& Arora, S. (2019). A conceptual framework for identifying key employee branding dimensions: A study of hospitality industry. Journal of Innovation \& Knowledge, 5(3), 200-209.

Du Preez, R., \& Bendixen, M. T. (2015). The impact of internal brand management on employee job satisfaction, brand commitment and intention to stay. International Journal of Bank Marketing, 33(1), 78-91.

Eisenberger, R., Fasolo, P., \& Davis-LaMastro, V. (1990). Perceived organizational support and employee diligence, commitment, and innovation. Journal of Applied Psychology, 75(1), 51.

Erkmen, E., \& Hancer, M. (2015). Linking brand commitment and brand citizenship behaviors of airline employees: "The role of trust". Journal of Air Transport Management, 42, 47-54.

Erkmen, E., Hancer, M., \& Leong, J. K. (2017). How internal branding process really pays off through brand trust. Tourism Analysis, 22(3), 309-322.

Erkmen, E. (2018). Managing your brand for employees: understanding the role of organizational processes in cultivating employee brand equity. Administrative Sciences, 8(3), 52.

Esteban-Sanchez, P., de la Cuesta-Gonzalez, M., \& Paredes-Gazquez, J. D. (2017). Corporate social performance and its relation with corporate financial performance: International evidence in the banking industry. Journal of Cleaner Production, 162, 1102-1110.

Ganesan, S., \& Hess, R. (1997). Dimensions and levels of trust: implications for commitment to a relationship. Marketing Letters, 8(4), 439-448.

Garbarino, E., \& Johnson, M. S. (1999). The different roles of satisfaction, trust, and commitment in customer relationships. Journal of Marketing, 63(2), 70-87.

Garas, S. R. R., Mahran, A. F. A., \& Mohamed, H. M. H. (2018). Internal corporate branding impact on employees' brand supporting behaviour. Journal of Product \& Brand Management, 27(1), 79-95.

Gounaris, S. P. (2005). Trust and commitment influences on customer retention: insights from business-to-business services. Journal of Business research, 58(2), 126-140.

Ha, B. C., Park, Y. K., \& Cho, S. (2011). Suppliers' affective trust and trust in competency in buyers. International Journal of Operations \& Production Management, 31(1), 56-77.

Hair, J. F., Risher, J. J., Sarstedt, M., \& Ringle, C. M. (2019). When to use and how to report the results of PLS-SEM. European Business Review.

Haque, A. U., \& Oino, I. (2019). Managerial challenges for software houses related to work, worker and workplace: Stress reduction and sustenance of human capital. Polish Journal of Management Studies, 19(1), 170-189.

Hayton, J. C., Carnabuci, G., \& Eisenberger, R. (2012). With a little help from my colleagues: A social embeddedness approach to perceived organizational support. Journal of Organizational Behavior, 33(2), 235-249.

Hofer, K. M., \& Grohs, R. (2018). Sponsorship as an internal branding tool and its effects on employees' identification with the brand. Journal of Brand Management, 25(3), 266-275.

Hurley, R., Gong, X., \& Waqar, A. (2014). Understanding the loss of trust in large banks. International Journal of Bank Marketing, 32(5), 348-366.

Ind, N., \& Riondino, M. C. (2001). Branding on the Web: A real revolution? Journal of Brand Management, 9(1), 8-19.

Ind, N. (2004). Living the brand: How to transform every member of your organization into a brand champion. Kogan Page Publishers.

Iyer, P., Davari, A., \& Paswan, A. (2018). Determinants of brand performance: the role of internal branding. Journal of brand Management, 25(3), 202-216.

Iyer, P., Davari, A., Zolfagharian, M., \& Paswan, A. (2019). Market orientation, positioning strategy and brand performance. Industrial Marketing Management, 81, 16-29.

Khairy, H. A., \& Lee, Y. M. (2018). Enhancing customers' brand commitment: a multidimensional perspective of brand citizenship behavior in Egyptian hotels. International Journal on Recent Trends in Business and Tourism, 2(1), 27-38.

Kim, W.G., Brymer, R.A. (2011). The effects of ethical leadership on manager job satisfaction, commitment, behavioral outcomes, and firm performance. International Journal of Hospitality Management, 30(4), 1020-1026. 
Kimpakorn, N., \& Tocquer, G. (2009). Employees' commitment to brands in the service sector: Luxury hotel chains in Thailand. Journal of Brand Management, 16(8), 532-544.

Kimpakorn, N., \& Tocquer, G. (2010). Service brand equity and employee brand commitment. Journal of Services Marketing, 24(5), 378-388.

King, C., \& Grace, D. (2008). Internal branding: Exploring the employee's perspective. Journal of Brand Management, 15(5), 358-372.

King, C. (2010). " One size doesn't fit all": Tourism and hospitality employees' response to internal brand management. International Journal of Contemporary Hospitality Management, 22(4), 517-534.

King, C., \& Grace, D. (2010). Building and measuring employee-based brand equity. European Journal of Marketing, 44(7/8), 938-971.

King, C., \& Grace, D. (2012). Examining the antecedents of positive employee brand-related attitudes and behaviours. European Journal of Marketing, 46 (3/4), 469-488.

King, C., \& Grace, D. (2009). Employee based brand equity: A third perspective. Services Marketing Quarterly, 30(2), 122-147.

King, C., Grace, D., \& Funk, D. C. (2012). Employee brand equity: Scale development and validation. Journal of Brand Management, 19(4), 268-288.

King, C., \& So, K. K. F. (2015). Enhancing hotel employees' brand understanding and brand-building behavior in China. Journal of Hospitality \& Tourism Research, 39(4), 492-516.

Leijerholt, U., Chapleo, C., \& O'Sullivan, H. (2019). A brand within a brand: an integrated understanding of internal brand management and brand architecture in the public sector. Journal of Brand Management, 26(3), 277-290.

Mampaey, J., Schtemberg, V., Schijns, J., Huisman, J., \& Wæraas, A. (2020). Internal branding in higher education: dialectical tensions underlying the discursive legitimation of a new brand of student diversity. Higher Education Research \& Development, 39(2), 230-243.

Meyer, J. P., Stanley, D. J., Herscovitch, L., \& Topolnytsky, L. (2002). Affective, continuance, and normative commitment to the organization: A meta-analysis of antecedents, correlates, and consequences. Journal of Vocational Behavior, 61(1), 20-52.

Miles, S. J., \& Mangold, G. (2004). A conceptualization of the employee branding process. Journal of Relationship Marketing, 3(2/3), 65-87.

Miles, S. J., Mangold, W. G., Asree, S., \& Revell, J. (2011). Assessing the employee brand: a census of one company. Journal of Managerial Issues, 23(4), 491-507.

Morgan, R. M., \& Hunt, S. D. (1994). The commitment-trust theory of relationship marketing. Journal of Marketing, 58(3), 20-38.

Morhart, F. M., Herzog, W., \& Tomczak, T. (2009). Brand-specific leadership: Turning employees into brand champions. Journal of Marketing, 73(5), 122-142.

Muhammad, S., Salleh, S. M., \& Yusr, M. M. (2019). The role of brand knowledge in explaining relationship between brand-centered communications and brand commitment: evidence from public banks Pakistan. Journal of distribution science, 17(1), 33-45.

Papasolomou, I., \& Vrontis, D. (2006). Using internal marketing to ignite the corporate brand: The case of the UK retail bank industry. Journal of Brand Management, 14(1/2), 177-195.

Peng, D. X., \& Lai, F. (2012). Using partial least squares in operations management research: A practical guideline and summary of past research. Journal of Operations Management, 30(6), 467-480.

Piehler, R., Hanisch, S., \& Burmann, C. (2015). Internal branding-Relevance, management and challenges. Marketing Review St. Gallen, 32(1), 52-61.

Piehler, R., King, C., Burmann, C., \& Xiong, L. (2016). The importance of employee brand understanding, brand identification, and brand commitment in realizing brand citizenship behaviour. European Journal of Marketing, 50(9/10), 1575-1601.

Piehler, R., Schade, M., \& Burmann, C. (2019). Employees as a second audience: the effect of external communication on internal brand management outcomes. Journal of Brand Management, 26(4), 445-460.

Porricelli, M. S., Yurova, Y., Abratt, R., \& Bendixen, M. (2014). Antecedents of brand citizenship behavior in retailing. Journal of Retailing and Consumer Services, 21(5), 745-752. 
Pramanik, S., \& Chatterjee, I. (2015). Intrinsic motivation, emotional intelligence, and perceived organizational citizenship behavior among employees in service organizations. Prabandhan: Indian Journal of Management, 8(12), 33-43.

Punjaisri, K., Evanschitzky, H., \& Wilson, A. (2009). Internal branding: an enabler of employees' brand-supporting behaviours. Journal of Service Management, 20(2), 209-226.

Punjaisri, K., \& Wilson, A. (2011). Internal branding process: key mechanisms, outcomes and moderating factors. European Journal of Marketing, 45(9/10), 1521-1537.

Rauyruen, P., \& Miller, K. E. (2007). Relationship quality as a predictor of B2B customer loyalty. Journal of business research, 60(1), 21-31.

Rhoades, L., \& Eisenberger, R. (2002). Perceived organizational support: a review of the literature. Journal of Applied Psychology, 87(4), 698.

Ringle, C. M., \& Sarstedt, M. (2016). Gain more insight from your PLS-SEM results. Industrial Management \& Data Systems.

Shaari, H., \& Hussin, Z. (2015). The effect of brand leadership styles on employees' brand citizenship behavior. Asian Social Science, 11(18), 86-92.

Terglav, K., Ruzzier, M. K., \& Kaše, R. (2016). Internal branding process: Exploring the role of mediators in top management's leadership-commitment relationship. International Journal of Hospitality Management, 54, 1-11.

Vatankhah, S., \& Darvishi, M. (2018). An empirical investigation of antecedent and consequences of internal brand equity: Evidence from the airline industry. Journal of Air Transport Management, $69,49-58$.

Wallace, E., \& De Chernatony, L. (2009). Service employee performance: its components and antecedents. Journal of Relationship Marketing, 8(2), 82-102.

Wallace, E., de Chernatony, L., \& Buil, I. (2011). How leadership and commitment influence bank employees' adoption of their bank's values. Journal of Business Ethics, 101(3), 397-414.

Wallace, E., de Chernatony, L., \& Buil, I. (2013). Building bank brands: How leadership behavior influences employee commitment. Journal of Business Research, 66(2), 165-171.

Wang, Y. C., Yang, J., \& Yang, C. E. (2019). Hotel internal branding: A participatory action study with a case hotel. Journal of Hospitality and Tourism Management, 40, 31-39.

Xiong, L., King, C., \& Piehler, R. (2013). "That's not my job": Exploring the employee perspective in the development of brand ambassadors. International Journal of Hospitality Management, 35, 348-359.

Xiong, L. (2014). Employee brand internalization: The central route to a brand aligned workforce (Doctoral Dissertation). Temple University.

Xiong, L., \& King, C. (2015). Motivational drivers that fuel employees to champion the hospitality brand. International Journal of Hospitality Management, 44, 58-69.

Xiong, L., \& King, C. (2018). Too much of a good thing? Examining how proactive personality affects employee brand performance under formal and informal organizational support. International Journal of Hospitality Management, 68, 12-22.

Xiong, L., So, K. K. F., Wu, L., \& King, C. (2019). Speaking up because it's my brand: Examining employee brand psychological ownership and voice behavior in hospitality organizations. International. Journal of Hospitality Management, 83, 274-282.

Yakovleva, M., Reilly, R. R., \& Werko, R. (2010). Why do we trust? Moving beyond individual to dyadic perceptions. Journal of Applied Psychology, 95(1), 79-91.

Yao, T., Qiu, Q., \& Wei, Y. (2019). Retaining hotel employees as internal customers: Effect of organizational commitment on attitudinal and behavioral loyalty of employees. International Journal of Hospitality Management, 76, 1-8.

Zeithaml, V. A., Parasuraman, A., \& Berry, L. L. (1985). Problems and strategies in services marketing. Journal of marketing, 49(2), 33-46. 